\title{
CCHCR1 Gene
}

National Cancer Institute

\section{Source}

National Cancer Institute. CCHCR1 Gene. NCI Thesaurus. Code C99623.

This gene may be involved in keratinocyte regulation. 